\title{
PETUAH BIJAK SEBAGAI EKSPRESI LITERASI SISWA DI MAN MODEL MANADO
}

\section{WISE ADVISE AS AN EXPRESSION OF STUDENTS LITERACY AT MAN MODEL MANADO}

\author{
Syarifuddin \\ Balai Penelitian dan Pengembangan Agama Makassar \\ Jl. AP. Pettarani No 72 Makassar \\ Email: syarifuddinamir84@yahoo.com
}

Naskah diterima tanggal 30 April 2018. Naskah direvisi tanggal 8 Mei 2018. Naskah disetujui tanggal 18 Mei 2018

\begin{abstract}
Abstrak
Ekspresi bijak siswa merupakan media komunikasi siswa dalam mengungkapkan daya positif mereka agar bisa diaplikasikan oleh dirinya sendiri maupun orang lain. Ekpresi ini tidak muncul sendirinya. Tetapi ia merupakan bentuk pengalaman literasi yang diperoleh dari berbagai sumber. Oleh karena itulah, penelitian ini ditujukan untuk mengkaji varian dan sumber petuah bijak siswa di MAN Model Manado Sulawesi Utara serta ekspresi ungkapan bijak siswa dengan menggunakan metode kualitatif serta pendekatan studi kasus. Pengumpulan data dilakukan dengan diskusi grup, wawancara, dokumentasi dan observasi. Varian petuah bijak di MAN Model Manado menunjukkan nuansa variatif yang beragam berupa kearifan lokal seperti motto atau pamali serta ungkapan bijak yang bersumber dari pesan-pesan agama dengan media bahasa yang cukup beragam pula seperti Bahasa Daerah, Bahasa Indonesia maupun Bahasa Asing. Keterkaitan antara literasi bijak dengan penguasaan bahasa sangatlah erat, artinya kemampuan siswa dalam mengekspresikan petuah bijak sangat dipengaruhi terhadap penguasaan bahasa. Dalam hal ini, literasi bijak dalam bahasa daerah sangat minim karena banyak siswa yang tidak menguasai bahasa daerah. Kreatifitas siswa dalam ekpresi ungkapan bijak pun sangat terbatas pada ungkapan bijak di majalah dinding, latihan pidato maupun lewat media sosial.
\end{abstract}

Kata Kunci: Petuah bijak, kearifan lokal, siswa, MAN Model Manado.

\begin{abstract}
Students wise expression is a form of media communication in some ways that can be applied by themselves and others. This expression does not appear by itself. It is also a form of literary experience from various sources. Therefore, this research aims to examine the variants and human resources in MAN Model Manado and the expression uses qualitative method and case study approach. Data collection will be conducted with group discussion, interview, documentation and observation. Variants of wise advice in MAN Model Manado show various nuances of local wisdom such as motto or pamali and wise expressions from religious messages with various tools as Regional Language, Indonesian Language and foreign language. The connection between wise literacy and language mastery is closely, means, the students' ability on wisdom expression is good advice to master the language. In this case, the wise literacy in language is very low because many students can't speak local language. Students' creativity in wise expression is very limited to the wall magazine expression, speech training and trough social media.
\end{abstract}

Keywords: Wise advise, local wisdom, student, MAN Model Manado.

\section{PENDAHULUAN}

Pendidikan negeri berkiblat ke barat Di sana anak-anak memang disiapkan untuk menjadi alat industri Dan industri mereka berjalan tanpa berhenti
Tetapi kita disiapkan menjadi alat apa?

Kita hanya menjadi alat birokrasi

Dan birokrasi menjadi berlebihan

Tanpa kegunaan

Menjadi benalu di dahan

(Rendra, Sajak Anak Muda) 
Di beberapa pesantren, materi terkait ungkapan-ungkapan bijak biasanya diajarkan dalam Mata Pelajaran Mahfudzat. Santri mulai dari tingkat menengah sampai tingkat atas disuguhi materi berupa ungkapan-ungkapan bijak sebagai bentuk motivasi dalam mengarungi kehidupan. Ungkapan seperti man jadda wajada (Barang siapa yang bersungguh-sungguh pasti akan dapat) yang sudah ditulis dalam bentuk novel dan difilmkan, dihapal di luar kepala berikut ungkapan-ungkapan bijak lainnya. Tujuan dari pembelajaran ini agar menjadi pegangan sekaligus motivasi hidup bagi santri ketika menuntut ilmu di pesantren hingga menjani kehidupan yang lebih menantang ke depan.

Di perguruan tinggi, Azhar Arsyad meluncurkan sebuah program andalan yang beliau sebut Pencerahan Imani dan Keterampilan Hidup yang disingkat dengan "PIKIH" pada tahun kedua dari kepemimpinannya di IAIN (kini UIN) Alauddin Makassar. Program ini ditujukan bagi mahasiswa baru selama dua semster dan menjadi prasyarat untuk mengikuti ujian konferehensif dan munaqasyah yang secara otomatis menjadi prasayarat kelulusan mahasiswa untuk memperoleh gelar sarjana. Pada dasarnya, program ini tidak berbeda dengan program rektor sebelumnya, yaitu Program Intensifikasi Bahasa Asing (PIBA) yang mengacu pada pendalaman Bahasa Arab dan Inggris untuk mahasiswa baru. Yang berbeda adalah adanya materi kuliah tambahan berupa ungkapan bijak yang dia susun dalam sebuah buku yang diberi judul "Retorika Kaum Bijak: Media Pembangkit Motivasi dan Daya Hidup Serta Penanaman Nilai-nilai dan Budi Luhur". Tujuan utama dari mata kuliah ini sebagaimana ia sebutkan dalam pengantar buku yaitu meningkatkan daya hidup dan daya kalbu. Ia kemudian menceritakan bahwa di Amerika Serikat, dikenal dengan sistem pendidikan yang disebut Liberal Arts Education. Sistem ini berupaya mendidik seseorang memiliki kapasitas pribadi yang dikembangkan secara dinamis untuk menghadapi situasi yang berbeda-beda. Tujuan akhir dari sistem ini yaitu menjadikan mahasiwa terdidik. Lebih lanjut ia memaparkan mata kuliah yang dirancang untuk membangkitkan daya hidup dan daya kesungguhan mahasiswa dalam menganalisis daya juang para tokoh dan ungkapan-ungkapan bijak mereka. Sayangnya sistem di atas menafikan daya kalbu. Oleh karena itu, Azhar Arsyad menambahkan dalam bukunya berupa materi pesan-pesan yang mengandung nilai keagamaan yang secara eksplisit memuat keistimewaan berupa materi akhlak dan komunikasi (dakwah). Secara khusus materi buku tersebut dikutip dari pelajaran dikenal dengan mahfudzat di dunia pesantren (Arsyad, 2005: i).

Hanya saja, kedua sistem pembelajaran petuah bijak tersebut di atas tidak mencantumkan ungkapan yang bersumber dari kearifan lokal nusantara. Akibatnya, identitas lokal sepertinya tereduksi di tengah gempuran kearifan yang bersumber dari luar. Problem berikutnya adalah materi petuah bijak seperti di atas tidak diperoleh secara langsung dalam mata pelajaran tertentu di lembaga pendidikan seperti madrasah secara umum termasuk pada siswa Madrasah Aliyah di Kota Manado sebagai lokasi penelitian. Padahal, materi bijak sangat penting itu mengembangkan daya kalbu siswa.

Menurut Ahmad Tohari (disampaikan dalam Workshop Pengembangan Soft Skill Sastra Religi Siswa, Tanggal 24-April 2016 di Makassar) bahwa kurikulum pendidikan kita terlalu didominasi pengembangan olah pikir sementara materi olah rasa seperti sastra justru sangat minin. Akibatnya banyak melahirkan para pemikir tapi minim daya rasa. Zuleha, lebih lanjut memaparkan bahwa pembelajaran sastra mestinya digalakkan sejak dini yaitu saat fase pendidikan dasar. Tujuannya yaitu menunjukkan kebenaran hidup, memperkaya rohani, memiliki kesantunan berbahasa dan menjadikan manusia berbudaya (Zuleha, 2013: 2023). Dalam hal ini petuah bijak sebagai karya sastra sangat penting untuk diajarkan.

Kondisi minimnya pembelajaran terkait petuah bijak di sekolah secara khusus diperparah dengan realitas serbuan media massa yang sangat mempengaruhi wacana anak ke depan. Dede Lilis dalam kajiannya menyebutkan bahwa dominasi televisi menjadi basis di tingkat sosial dalam merepresantasikan idealisasi anak. Dilema kultural kalangan dewasa, budaya baca yang rendah, dan beroperasinya mekanisme pasar dalam sistem pendidikan turut memperkuat hegemoni televisi (Lilis, 2014: 169). Pada akhirnya, anak lebih mengenal ungkapan-ungkapan yang bersumber dari televisi yang dituturkan oleh iklan, artis sinetron atau aktor yang belum tentu punya nilai bijak. Ditambah lagi kurang berfungsinya sensor lembaga terkait terhadap tontonan yang dianggap belum layak buat anak-anak maupun remaja.

Oleh karena itu, penelitian ini mencoba menyasar potensi petuah bijak pada siswa Madrasah Aliyah sebagai ekspresi literasi siswa, dengan menfokuskan pada ingatan dan ekpresi bijak siswa 
Madrasah serta dari mana saja mereka memperoleh ungkapan tersebut dikarenakan materi ini tidak diajarkan secara langsung. Pemilihan Kota Manado didasarkan pada alasan bahwa posisi Manado yang identik dengan etnis Minahasa yang mayoritas beragama Kristen, sehingga dalam hal ini siswa madrasah menjadi komunitas minoritas. Oleh karena itulah, kajian ini menjadi menarik untuk dikaji dengan memotret bagaimana literasi siswa Madrasah Aliyah (yang beragama Islam) berupa ungkapan bijak terkhusus yang bersumber dari kearifan lokal.

Pengunaan petuah bijak yang menjadi tradisi masyarakat bisa dianggap dapat memberi arti hidup dan memperteguh kepribadian bangsa. Ia seyogyanya tumbuh mekar di taman jiwa siswa bilamana sekolah atau madrasah masih dilambangkan sebagai sentrum peradaban. Akan tetapi kenyataannya, citra siswa di era kekinian telah didera oleh isu kenakalan dan bahkan dinilai buruk dalam budaya literasi. Kondisi ini menimbulkan tanya, tentang bagaimanakah sesungguhnya petuah bijak yang kini berkembang dalam dunia siswa, dan bagaimana itu dapat dimanfaatkan. Karena itulah problem penelitian ini dititik beratkan pada, Bagaimana petuah bijak itu diaplikasikan oleh siswa MAN Model Manado untuk pengembangan budaya literasi? Secara teknis rumusan masalah ini dijabarkan sebagai berikut: 1. Bagaimana varian petuah bijak pada siswa Madrasah Aliyah Negeri Model Manado? 2. Bagaimana ekspresi petuah bijak dalam budaya literasi siswa Madrasah Aliyah Negeri Model Manado?

Tujuan umum penelitian ini yaitu "Mengungkap aplikasi petuah bijak dalam rangka pengembangan literasi siswa". Sedangkan tujuan khusus adalah jawaban yang akurat terhadap pertanyaan-pertanyaan tersebut yang diangkat sebagai masalah penelitian, yaitu: Mendeskpriskan varian petuah bijak pada siswa Madrasah Aliyah Negeri Model Manado dan memaparkan bentuk ekspresinya dalam budaya literasi siswa. Hasil penelitian ini diharapkan menjadi acuan dan pertimbangan bagi Madrasah Aliyah sebagai sasaran penelitian serta Kementerian Agama dalam pengembangan kurikulum berkaitan dengan petuah bijak siswa khususnya petuah bijak religi dalam pengembangan budaya lietrasi siswa.

Petuah bijak yang dimaksud di sini adalah pesan-pesanberupa; ungkapan tradisional, (pepatah, peribahasa, semboyan), nyanyian rakyat, bahasa rakyat berupa dialek, julukan, sindiran, bahasa rahasia, bahasa remaja, dan sejenisnya. Dalam kajian ini, termasuk pula petuah bijak yang bersumber dari pesan-pesan orang tua, guru, maupun sumber lainnya. Petuah bisa juga dimaknai sebagai bagian dari pepatah selain sanggahan (Hidayat, 2006: 258). Secara garis besar sebagaimana dikutip dari Wikipedia (diakses tanggal 7 Oktober 2016) bahwa kategorisasi pepatah (dalam terminologi Inggris dikenal dengan sebutan "saying") dibagi menjadi beberapa macam, yaitu:

Aphorism - A saying that contains a general, observational truth; "a pithy expression of wisdom or truth. (petitih yang mengandung kebenaran umum dan dapat diamati, petitih yang bernas tentang kearifan dan kebenaran).

Apophthegm - [A]n edgy, more cynical aphorism (ekspresinya menganggu, beraroma aforisme sinis).

Epithet - A descriptive word or saying already widely associated with a particular person, idea, or thing. (petitih deskriptif atau petitih yang dikaitkan dengan orang, ide, atau hal tertentu).

Idiom - A saying that has only a non-literal interpretation; "an expression whose meaning can't be derived simply by hearing it. (petitih yang hanya memiliki interpretasi non-literal ; “ Ungkapan yang maknanya tidak dapat diturunkan hanya dengan mendengarnya).

Motto - A saying used frequently by an individual person or group to concisely state their general outlook or intentions. [petitih yang sering digunakan oleh orang atau kelompok untuk secara ringkas menyatakan pandangan dunianya (world view)].

Quip - A clever or funny saying based on an observation. (petitih pintar atau jenaka yang didasarkan pada pengamatan).

Selanjutnya, kajian ini akan difokuskan pada petuah bijak yang diekpresikan oleh siswa, yaitu petuah yang mengandung pesan atau nilai luhur berupa; ungkapan, peribahasa, kata mutiara, motto atau kalimat yang melekat dalam hati sanubari. Sedangkan literasi yang dimaksud dalam penelitian ini adalah terkait dengan aktifitas membaca, menulis dan menyimak. Atas defenisi ini maka yang 
menjadi fokus pengamatan adalah petuah bijak yang diketahui oleh siswa dari berbagai sumber, dan petuah bijak apakah yang diaplikasikan untuk memperkuat budaya literasi.

Kajian ini menjadi lebih menarik mengingat kajian serupa berupa ungkapan bijak secara khusus masih sangat minim di Manado masih terbilang minim. Ada beberapa kajian yang bersinggungan dengan kajian namun secara namun memiliki perbedaan mendasar. Di antara kajian bedasarkan penelusuran dari bebeberapa literatur yaitu kajian terkait tentang kearifan lokal yang bisa dibaca pada dua hasil penelitian tim di dua lokasi berbeda oleh para Peneliti Balai Pelestarian Nilai Budaya Manado. Pertama, Kearifan Lokal Kaitannya dengan Pembentukan Watak dan Karakter Bangsa di Kab. Bolmong Selatan oleh Pitres Sombowadile dkk. Kajian ini mengupas secara luas kearifan lokal pada masyarakat mencakup syair-syair lokal, kalimat rumusan filosifis hingga praktik hidup. Kaitannya dengan kajian petuah bijak siswa yaitu ada pada pembahasan tentang kalimat rumusan filosofis (Sombowadile, 2012: 309-310). Kajian yang hampir sama juga dipaparkan oleh oleh Salmin Djakaria dan Hendri Gunawan dengan tema "Ungkapan dan Tradisi bercirikan Pembentukan Watak dan Karakter Bangsa di Minahasa. (Djakaria, 2014: 185). Secara umum, kedua kajian tersebut menyimpulkan bahwa kearifan lokal termasuk petuah bijak sangat penting dipahami untuk membentuk watak dan karakter bangsa.

Tulisan Rosdianayangberjudul "Implementasi Pendidikan Karakter di MAN Model Manado”. Kajian ini memotret proses integrasi 18 karakter kebangsaan dalam kurikulum, yaitu; religus , jujur, toleransi, disiplin, kerja keras, kreatif, mandiri, demokratis, rasa ingin tahu, semangat kebangsaan, cinta tanah air, menghargai prestasi, bersahabat/ komunikatif, cinta damai, gemar membaca, peduli lingkungan peduli sosial dan tanggung jawab. Salah satu sumber dari nilai karakter itu adalah ungkapan bijak dari kearifan lokal "Sitou timou tumou tou" (Rosdiana, 2104: 250-263).

Penelitian lain yang dilakukan oleh $\mathrm{Abu}$ Muslim (2016: 109-122) yang diberi judul "Kitorang Samua Basudara: Bijak Bestari Di Bilik Harmoni.” Kajian ini difokuskan pada peran beberapa kearifan lokal (termasuk kearifan lokal verbal “Torang Samua Basudara") dalam kaitannya dengan penguatan kerukunan umat beragama di Kota Manado. Menurut kajian ini, kearifan lokal "Kitorang Samua Basudara" telah terinternalisasi dan melembaga dalam masyarakat Manado, sehingga menjadi elemen penting dalam menciptakan kerukunan berdasarkan rasa persaudaraan orang-orang Manado secara kolektif.

\section{Tinjauan Pustaka}

Eriyanto mendeskripsikan Teori Representasi yaitu tatacara bagaimana suatu objek atau realitas ditampilkan, atau juga sebagai konsep yang digunakan dalam proses sosial pemaknaan melalui sistem penandaan (dialog, tulisan, video, film, fotografi dan lain sebagainya). Dari perspektif bahasa yaitu bagaimana menampilkan sesuatu dengan bahasa yang baik. Sementara dari persepekif wacana, representase digunakan untuk menunjuk pada suatu istilah bagaimana peristiwa tersebut dilaporkan (Eriyanto, 2001: 311).

Untuk mendukung teori tersebut di atas, digunakan juga Teori Semiotika ala Peirce. Dalam hal ini, semiotika dimaknai sebagai studi tanda dan segala yang berhubungan dengan tanda. Oleh karena itu, tanda tidak hanya melekat pada bahasa dan kebudayaan tetapi intrinsik pada seluruh fenomena alam. Melalui tanda manusia dapat memaknai kehidupan dengan realitas. Pada tataran ini, bahasa dianggap sebagai tanda yang paling fundamental. Sementara tanda-tanda non verbal dipandang sebagai sejenis bahasa yang tersusun dari tanda-tanda bermakna yang dikomunikasikan berdasarkan relasi-relasi (Rusmana, 2014: 107). Di antara pemikiran Semiotik Pierce yang paling penting yaitu pemilihan tanda berdasarkan tipologi tanda yaitu ikon, indeks dan simbol.

Sementara itu konsep literasi pada dasarnya selalu berkaitan dengan dua kecakapan utama aktifitas membaca dan menulis. Lebih jauh yaitu memahami secara kritis tentang apa yang dibaca dan ditulis serta mengkomunikasikannya kepada pihak lain (Adiputra, 2008: 4). Oleh karena itu, literasi disebut sebagai kemampuan kolaboratif berbahasa dan berpikir dengan inti kegiatan membaca, berpikir, dan menulis yang dilakukan oleh seseorang dalam rangka memanfaatkan secara optimal berbagai sumber baik yang tercetak maupun yang tidak tercetak untuk berbagai keperluan. Literasi akademik siswa di madrasah adalah proses bagaimana siswa mengembangkan budaya literasi, artinya pengembangan kesadaran, motivasi, keterampilan, kegemaran berliterasi yang tinggi dari siswa di madrasah untuk keperluan akademik maupun non-akademik. Literasi akademik dimaknai sebagai pemanfaatan dari 
sinergi kemampuan membaca, berpikir-kritis, menulis yang diterapkan secara lintas bidang studi (Kusumo, 2013: 1).

\section{METODE PENELITIAN}

Penelitian ini merupakan penelitian kualitatif deskriptif dilaksanakan di MAN Model Manado Provinsi Sulawesi Utara. Pemilihan lokasi dilakukan berdasarkan pertimbangan rekomendasi dari hasil workshop soft skill karya sastra religi di Makassar tahun 2016. Siswa yang mengikuti workshop tersebut telah merepresentasikan tingkat kesadaran budaya literasi siswa dari Madrasah Aliyah yang cukup baik pada lokasi yang dipilih. Sehingga upaya melacak petuah bijak yang dapat digunakan untuk menguatkan literasi siswa diyakini sudah tepat sasaran.

Teknik pengumpulan data dilakukan melalui: Fokus Group Discussion (FGD) dengan beberapa kelompok siswa terkait ekpresi bijak di madrasah serta wawancara dengan informan yang relevan juga dilakukan seperti kepada siswa, guru dan kepala madrasah. Teknik pengumpulan data seperti ini sangat identik dengan penelitian kualitatif. Teknik pengumpulan data lainnya yaitu studi pustaka dan dokumen yang berkaitan dengan petuah bijak dan budaya literasi siswa disertai dengan observasi terhadap lingkungan siswa yang menjadi sasaran penelitian. Waktu pengumpulan data dibagi penjadi dua tahap yaitu; tahap pengumpulan data awal dan tahap pengumpulan data kedua.

Data yang dikumpulkan dalam penelitian ini mengenai data tentang varian petuah bijak pada siswa Madrasah Aliyah yang meliputi: petuah bijak apa saja yang berada di dunia siswa, makna petuah bijak yang berkaitan dengan budaya literasi siswa, dan bagaimana petuah bijak dapat diekspresikan sebagai representasi dari budaya literasi siswa.

Data ekspresi petuah bijak selanjutnya akan dianalisis dengan pemaparan yang bersifat deskriptif naratif melalui pendekatan semiotika. Salah satu ciri penelitian kualitatif, yang menjadi instrumen utama adalah peneliti itu (Sugiyono, 2010: 305). Oleh karena itu, dalam penelitian ini analisis data telah dilakukan sejak penelitian ini berlangsung hingga berakhirnya proses pengumpulan data.

\section{PEMBAHASAN}

\section{Sumber Petuah Bijak Siswa}

Pertama kali ketika menginjakkan kaki memasuki pintu gerbang MAN Model Manado Manado, pengunjung akan disuguhkan dengan pemandangan adanya papan reklame ungkapan bijak bertuliskan "10 Budaya malu: Malu melanggar tata tertib madrasah, Malu malas belajar, Malu dimarahi guru, Malu mendapat hukuman guru, Malu berkata bohong, Malu bersikap sombong, Malu menyontek, Malu mendapat nilai kurang Malu berlaku curang, Malu prestasi menurun." Papan reklame ini merupakan sajian pembuka dari beberapa papan reklame yang sengaja disuguhkan oleh madrasah yang bisa ditemui di sisi jalan, dinding gedung madrasah kantin dan lain sebagainya. Fungsingya, sebagai media edukasi dan penanaman nilai bijak pada siswa. Disamping papan reklame tersebut, tranformasi nilai bijak juga sering disampaikan secara lisan oleh para pembina di madrasah sebagai bentuk edukasi nilai moral secara langsung dalam berbagai kesempatan. Hanya saja kelemahan dari media lisan ini yaitu ingatan siswa sangat tergantung dari kesan yang kuat dari setiap pesan-pesan bijak. Tidak adanya kodifikasi dalam bentuk tulisan yang bisa mengingatkan kembali sewaktu-waktu ketika hendak dimunculkan kembali menyebabkan pesan-pesan bijak tersebut sering menguap tanpa jejak di benak siswa.

Salah satu di antara sumber literasi bijak siswa juga yaitu ungkapan dalam kearifan lokal yang sudah menjadi motto di daerah asal siswa. Motto ini sendiri sudah terpatri dalam pikiran siswa walaupun tidak memahami secara mendalam makna filosofi dari ungkapan tersebut. Ingatan siswa ini terkait kearifan lokal biasanya diperoleh dari pesan-pesan yang biasa disampaikan oleh guru, pejabat publik yang sering menggunakanungkapan tersebut ataupun media papan reklame yang biasanya bisa ditemui di layanan publik seperti bandara maupun jalan-jalan protokol. Di samping itu, peran media massa lokal memiliki andil ynag cukup besar. Sebagaimana yang dipaparkan Sumampouw terkait sosialisasi "Torang Samua Basudara" dengan menyebutkan beberapa judul pemberitaan media (Sumampouw, 2015: 88-90). Kearifan lokal ini sendiri sudah menjadi identitas lokal masyarakat termasuk siswa walaupun tidak diajarkan secara formal di kelas. Nampaknya, komunikasi secara massif yang dilakukan oleh berbagai pihak menjadikan ungkapan kearifan lokal seperti torang samua basudara (kita semua bersaudara), sitou timou tumou tou (manusia dilahirkan dan hidup sebagai manusia), mototampiaan, mototabiaan, bo mototonoban (saling memperlakukan dengan baik, saling menyayangi, saling mendukung), menjadi sangat familiar bagi siswa walaupun sang siswa bukan termasuk dari suku asal ungkapan tersebut. 
Ketidakpahaman siswa terhadap makna konsep dari kearifan lokal bisa dipahami karena kajian tentang itu masih sangat minim. Menurut Jan Tinggogoy, (2002: 15) dalam menelisik makna falsafah "tumou tou", walaupun perkataan ini begitu populer di seluruh lapisan masyarakat Minahasa baik itu yang ada di Minahasa, di luar maupun di mancanegara, namun pertanyaan sampai saat ini belum terjawab adalah oleh siapakah dan kapankah falsafah hidup itu diungkapkan, dicanangkan, diajarkan dan diaplikasikan dalam kehidupan orang Minahasa? Penjelasan hampir sama juga dipaparkan oleh A.J. Sondakh, 2008: 36) yang diawali dengan defenisi secara sederhana kaitannya dengan misi humanistik yaitu "manusia hidup untuk menghidukan sesama manusia." Selanjutnya makna konsep dari ungkapan ini dijelaskan detail. Nampaknya pemahaman sederhana ini sejalan dengan pemahaman siswa berdasarkan hasil diskusi dimana falsafah ini dimaknai:

"Manusia hidup di dunia untuk menghidupi, mendidik dan menjadi berkat untuk orang lain." (Wawancara dengan Fadillah Bachmid siswa Kelas Sosial XI 2 MAN Model Manado, 30 Agustus 2016).

Minimnya kajian tentang kearifan lokal juga berbanding lurus dengan koleksi perpustakaan madrasah yang kurang memuat karya-karya sastra seperti puisi, novel, maupun cerpen. Koleksi perpustakaan lebih banyak diisi dengan buku-buku pelajaran inti. Sementara itu juga pembelajaran kesusastraan sangat minim, itupun diintegrasikan ke dalam pelajaran Bahasa Indonesia dengan porsi yang sedikit.

Di samping earifan lokal yang sudah menjadi motto daerah, sumber pesan bijak siswa juga bisa dilihat pada pesan-pesan pamali (larangan lokal) yang diperoleh dari orang tua, paman kakek maupun orang yang dituakan di daerah asal siswa. Oleh (Pitres dkk), dimaknai sebagai kercayaan dan pantangan dengan menyebutkan beberapa pantangan yang ada pada masyarakat Bolaang Mongondow Selatan (Sombowadile, 2012: 264-265). Melalui interview yang dilakukan terhadap siswa, pada dasarnya mereka dibekali pesan pamali yang begitu banyak dan beragam sebagai petuah yang harus dipatuhi, namun satu hal kondisi psikologi yang siswa yang kurang memahami makna filosofi serta pemahaman keyakinan siswa dari setiap pesan maupun yang menjadi kendala sehingga pesanpesan pamali tersebut banyak yang terlupakan.
Menurut pengakuan dari salah seorang siswa:

"Sebenarnya banyak kak pesan pamali dari orang-orang tua, tapi kita anggap itu sesuatu takhayul jadi kita tidak percaya" (Wawancara dengan Arya Patonti Siswa MAN Model Manado, 30 Agustus 2016)

Varian pesan pamali yang diterima oleh siswa dari segi tema cukup beragama walaupun secara umum merupakan pesan, panduan maupun arahan dalam kehidupan sehari-hari yang secara filosofi memiliki makna yang tidak semuanya bisa dimaknai secara tepat oleh siswa. Berikut beberapa ungkapan pamali dari siswa umumnya berasal dari Bahasa Mongondow dengan mencantumkan penerjemahan/pemaknaan dari siswa itu sendiri:

Aka monimpat dika lumbuan bononknya kon muna, lumbuk kon tumi (Jika kita menyapu, apabila rumput/sampahnya di buang ke depan seperti menolak rezeki yang akan datang).

Aka manginum kon simbuyung, tampatnya dika polongagon po tongkuban (Setelah meminum kelapa muda, jangan dibiarkan terbuka begitu saja tetapi ditelungkupkan).

Dika momangko kon konduku dolam-dolam (Jangan memotong kuku malam hari).

Aka ayuan intau sioha baloi dika bi masindog kon tolingkop baloi (Kalau ada orang hamil di rumah, jangan berdiri di pintu rumah).

Jika kita menyapu di dalam rumah, semua sampah dan debu dikumpul tengah-tengah rumah dan diangkat.

Aka mogousing koubuak, buak lukatua porosisip pangkoi tagiu (kalau memotong rambut harus disisipkan di batang pisang).

Aka mo iba diya woka uli kan soe bo poliu in $C D$ (Kalau mau keluar kemana-mana celana dalam harus diperbaiki agar kejadian sial yang akan menimpa kita pergi jauh-jauh).

Perempuan tidak boleh keluar malam.

\section{Bahasa Petuah Bijak}

Bahasa merupakan media komunikasi yang paling utama. Setiap ide, gagasan, pemikiran 
yang ketika hendak disampaiakan diperlukan menggunakan bahasa yang baik. Tak terkecuali dalam ungkapan bijak siswa. Penguasaan bahasa siswa tentu sangat mempengaruhi varian petuah bijak yang dimiliki siswa. Artinya ketika siswa tidak menguasai bahasa tertentu maka hampir bisa dipastikan bahwa siswa tersebut tidak memiliki literasi berkaitan dengan bahasa tersebut termasuk ungkapan bijak. Dalam kaitannya dengan pembelajaran di MAN Model Manado, pengajaran Bahasa lebih difokuskan pada pembelajaran Bahasa Indonesia serta bahasa asing yaitu Bahasa Arab dan Inggris. Akibatnya, bisa diprediksi bahwa varian petuah bijak siswa lebih dominan dari bahasa-bahasa tersebut. Ini tentu menjadi problem jika dibaca dari perspektif identitas lokal siswa yang semakin tergerus. Hal ini diamini oleh Kepala MAN Model Sarpin Hamzah (Wawancara, 26 Agustus 2016). Lebih lanjut ia memaparkan bahwa kebijakan madrasah yang meniadakan pembelajaran Bahasa Daerah sangat mempengaruhi degradasi identitas lokal tersebut. Menurutnya juga, kondisi Manado yang heterogen juga salah satu penyebabnya, sehingga di Manado tidak ada bahasa daerah yang betul-betul dianggap mewakili warga Manado secara keseluruhan. Ini bisa dilihat pada posisi Manado sebagai ibukota Provinsi Sulawesi Utara yang memiliki beberapa bahasa daerah yang tersebar di wilayah Minahasa, Bolaang Mongondow, Sangir dan Talaud. Desmita (2016: 55) menyebutkan, bahwa salah faktor yang sangat mempengaruhi keberhasilan atau kegagalan dalam apek penguasaan bahasa anak yaitu faktor pembawaan dan lingkungan.

Kini, bahasa sehari-hari masyarakat Manado (termasuk siswa MAN Model) adalah bahasa Melayu Manado yang dalam tulisan (A.B.G. Rattu, 1997: 122-123) disebutkan bahwa Bahasa Melayu Manado telah menjadi bahasa perantara antar etnis di Manado. Bahkan bahasa Melayu Manado diyakini telah digunakan oleh Missionaris Belanda sejak tahun 1675 pada saat ibadah di gereja-geraja di Minahasa. Hingga akhirnya bahasa ini menjadi bahasa persatuan (lingua pranca). Kenyataan ini tentu mengancam keberadaan bahasa daerah. Menurut Sombowadile (2012: 139) dengan mengutip situs etholog, ada beberapa bahasa di Sulawesi Utara yang terancam punah seperti bahasa Bolango yang diduga hanya memiliki sekitar 5.000 penutur serta bahasa Atinggola yang dekat dengan bahasa Bolango yang diduga hanya memiliki 15.000 penutur.
Pada akhirnya, petuah bijak siswa yang mendominasi sudah barang tentu dari Bahasa Melayu Manado sebagai bahasa persatuaan disamping bahasa asing berupa Bahasa Arab dan Bahasa Inggris. Kalaupun ada petuah bijak yang berbahasa daerah, itu berasal dari ungkapan kearifan lokal yang menjadi slogan daerah dan sudah terekam secara umum dalam ingatan siswa. Misalnya ungkapan "Sitou Timou Tumou Tou" yang sebagian besar siswa mengetahui ungkapan tersebut.

Petuah bijak siswa ditinjau dari segi bahasanya berdasarkan hasil pengumpulan data dari siswa sebagaimana berikut ini:

Berbahasa Daerah

- Sitou timou tumou tou (Manusia dilahirkan dan hidup sebagai manusia) dari Bahasa Minahasa.

- Sumikola (semua harus bersekolah) dari Bahasa Minahasa.

- Singog tonggina indongoggan jalan mo tulid in tutuyan (Dengarlah nasehat dan ikuti jalan yang lurus) dari Bahasa Bolang Mongondow.

- San siote san pate-pate (bersatu dalam perbedaan) dari Bahasa Talaud.

- Pleskora pekapia (Sekolah yang baik) dari Bahasa Sangir .

Berbahasa Melayu Manado

- Torangsamuabasudara (Kita semuabersaudara).

- Brenti jo bagate (berhenti minum/mabuk).

- Mo miskin ka'bi asal dika mo rinut (Biar miskin tapi jangan pelit).

- Senyum nda bekeng rugi (senyum tidak merugikan siapapun).

- Jang cuma tau di mulu kong nyanda beking (Jangan hanya tahu mengatakan tapi tidak diamalkan).

- Ngana boleh kalo ngana bapikir ngana boleh (Kamu bisa kalau berpikir bisa).

- Hidup jo bae-bae kuat bakalae kalakuang bisae torang buang lebe bae (Hiduplah dengan baik, jangan berkelahi, perbuatan jelek lebih baik disingkirkan).

- Kalo bulum kalar sekolah jang dulu batona (kalau belum selesai sekolah jangan dulu pacaran) .

Berbahasa Indonesia

- Hargailah gurumu karena gurumu adalah orang tua kedua dari orang tuamu.

- Kesempatan itu tidak akan datang kedua kalinya.

- Jangan risaukan nikmat yang belum kita miliki, tapi risaulah akan nikmat yang belum kita . 
- Menuntut ilmu adalah taqwa, menyampaikan ilmu adalah ibadah, mengulang-ulang dalah dzikir, mencari ilmu adalah jihad.

Berbahasa Arab

\section{مَنْ جَدَّ وَجَدَ}

Barang siapa bersungguh-sungguh ia dapat

Waktu lebih berharga dari emas

$$
\text { الْوَقَتُ أَثَثَنْ مِنَ النَّهَبِ }
$$

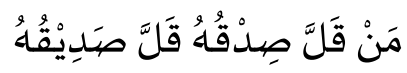

Barangsiapa yang sedikit perkataannya jujurnya maka sedikit pula temannya.

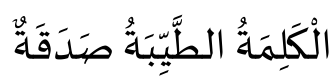

Kalimat (perkataan) yang baik itu adalah sedekah.

\section{Berbahasa Inggris}

- Save water, save life, and save the world.

- (jaga air, jaga jaga kehidupan dan jaga bumi).

- Education is not the learning of fact, but training of mind to think.

- (Pendidikan bukan sekedar belajar pada kenyataan (fakta) tetapi juga melatih pola pikir).

- Open your mind before open you mouth.

- (Buka pikirannmu sebelum membuka mulutmu untuk berbicara) .

\section{Kategorisasi Petuah Bijak Siswa}

Setelah melakukan inventarisasi varian petuah bijak siswa di MAN Model Manado, maka kategori petuah bijak siswa sebagaimana berikut:

Aphorism (petitih yang mengandung kebenaran umum dan dapat diamati, petitih yang bernas tentang kearifan dan kebenaran). Misalnya: torang samua basudara (kita semua bersaudara), brentijo bagate (berhenti minum/ mabuk), Singog tonggina indongoggan jalan mo tulid in tutuyan (Dengarlah nasehat dan ikuti jalan yang lurus) dan lain sebagainya.

Apophthegm (ekspresinya menganggu, beraroma aforisme sinis). Misalnya ungkapan: "Ketika nilai bagus lebih dihargai daripada kejujuran maka mulailah mencontek, diupayakan untuk memperoleh pengakuan tersebut.

Epithet (petitih deskriptif atau petitih yang dikaitkan dengan orang, ide, atau hal tertentu). Misalnya ungkapan : "Ketika seseorang menghina kamu, itu adalah sebuah pujian bahwa selama ini mereka menghabiskan banyak waktu untuk memikirkan kamu, bahkan ketika kamu tidak memikirkan mereka (BJ. Habibie)" atau "Bangsa yang besar adalah bangsa yang menghargai jasa pahlawannya (Sukarno)".

Idiom (petitih yang hanya memiliki interpretasi non-literal ; " Ungkapan yang maknanya tidak dapat diturunkan hanya dengan mendengarnya). Misalnya: sitou timou tomu tou (manusia memanusiakan manusia), sumikola (semua harus bersekolah).

Motto [petitih yang sering digunakan oleh orang atau kelompok untuk secara ringkas menyatakan pandangan dunianya (world view)]. Misalnya ungkapan yang sudah menjadi motto daerah: yaya $u$ santi (Angkat pedangmu; berani dan berusahalah), mototampiaan, mototabiaan, bo mototonoban (saling memperlakukan dengan baik, saling menyayangi, saling mendukung), san siote san pate-pate (persatuan dan kesatuan dalam perbedaan).

Quip (petitih pintar atau jenaka yang didasarkan pada pengamatan). Misalnya ungkapan: "Bolos bareng, main bareng, nyontek bareng, mudah-mudahan setelah lulus kita sukses bareng."

Jika dilihat dari variasi petuah bijak di MAN Model Manado bisa disimpulkan bahwa ungkapan bijak tersebut hanya pada seputar aphoris, idiom, motto dan quip. Sementara ungkapan yang bermakna apophthegm (lawan aphoris), klise, epigram, mantra maupun yang lainya termasuk langka kalaupun bisa dikatakan sulit ditemukan. Ini bisa dipahami karena dunia siswa adalah dunia polos. Dunia siswa adalah dunia remaja yang merupakan peralihan dari masa kanak-kanak ke masa dewasa yang dikenal dengan masa remaja yang ditinjau dari aspek pemikirin kritis distilahkan pada gradasi abu-abu bukan lagi melihat secara hitam putih (Desmita, 2016: 158). Ekpresi-eksrepsi bijak pun cenderung sangat normatif. Namun demikian, variasi ungkapan bijak tersebut adalah sebuah potensi positif yang membutuhkan polesan dalamm bentuk pengembangan literasi siswa. 


\section{Ekspresi Petuah Bijak}

Salah satu kelebihan dari MAN Model Manado adalah madrasah ini dilengkapi dengan berbagai macam fasilitas. Salah satu di antaranya adalah bangunan masjid yang cukup besar dengan desain dua lantai yang diberi nama Masjid Darul Ulum yang berarti "Negeri Ilmu Pengetahuan" dengan harapan dari masjid ini terlahir ilmuwanilmuwan muslim. Uniknya, masjid ini dibangun berasal dana sumbangan siswa yang dikenal dengan gerakan Rp. 1000/hari hingga bisa terkumpul lebih Rp. 1 milyar. Bangunan ini mampu menampung lebih 1.000 siswa. Keberadaannya cukup membantu dalam mendukung proses pendidikan dan pengajaran di madrasah khususnya pada pembinaan mental dan karakter. Setiap waktunya, diadakakan salat berjama'ah di masjid. Salah satu di atntara pembinaan mental siswa yaitu latihan pidato yang disampaikan oleh siswa setiap selesai salat zhuhur. Kegiatan ini ditujukan agar siswa MAN Model Manado mampu mengemban amanah sebagai muslim penyebar kebaikan di masyarakat. Tema yang disampaikan siswa pun bebas. Dalam kesempatan ini, siswa menyampaikan petuah bijak dalam bentuk ungkapan-ungkapan kepada audiens. Hanya saja, latihan pidato dilaksanakan tanpa konsep naskah pidato sehingga dokumentasi terkait materi khususnya yang memuat petuah bijak sulit dilacak.

Ekspresi petuah bijak siswa adalah bentuk representasi siswa terhadap nilai-nilai bijak. Representasi siswa merupakan pilihan siswa dalam menyampaikan gagasan-gagasan baik secara verbal maupun non verbal. Di sini melihat ekspresi yang sangat dominan di MAN bisa dilihat pada majalah dinding siswa. Ketika kita berjalan di setiap sudut kelas MAN Model Manado maka kita akan mendapatkan pemandangan yang cukup menarik berupa dinding kelas yang dihiasi dengan berbagai macam coret-coretan. Ini merupakan bagian dari ekspresi kreatif siswa dalam menghiasi kelas. Namun demikian coretan tersebut bukanlah sekedar coretan yang tidak bernilai. Setiap tampilan coretan berupa kata-kata verbal maupun lukisan memiliki makna tertentu yang ingin disampaikan. Dalam hal ini coretan-coretan tersebut adalah proses konvensi antar anggota kelas, walaupun pada kelas tertentu setiap siswa kadang juga diberikan keleluasaan mengeksprsikan gagasaannya secara individu sehingga pembaca bisa memaknai sendiri dari berbagai perspektif.
Coretan pada dinding yang lebih dikenal dengan majalah dinding merupakan tradisi yang sudah berlangsung lama di MAN Model Manado. Tradisi ini pun sangat didukung oleh Sarpin Hamzah Kepala MAN Model Manado. Dalam wawancara (26 Agustus 2016), ia menuturkan:

Tradisi menghiasi kelas dengan dengan majalah dinding sudah berlangsung jauh sebelum saya menjadi pimpinan di sini. Hanya saja, pada tahun ini kita memotivasi secara besar-basaran pada siswa dan diperlombakan. Kelas yang paling kreatif akan diberi hadiah. Saya bilang pada siswa: silakan coret-coret dinding ini sesuka hatinya selama dalam batas kewajaran dan kesopanan.

Hasil coretan siswa pun cukup beragam dan sangat sarat dengan pesan-pesan bijak yang bisa menjadi motivasi buat siswa dalam menjalani kehidupannya sebagai seorang pelajar maupun dalam menggapai cita-citanya di masa yang akan datang. Misalnya pada kelas XII Agama 2 dengan memuat banyak petuah bijak disamping memuat grafik menarik yang bertemakan dengan Hari Kemerdekaan RI dengan asesoris hiasan serba warna merah dan putih. Pada coretan itu terdapat banyak pesan-pesan bijak dari setiap siswa yang dikutip dari Alquran, pesan-pesan agama, ungkapan tokoh maupun pesan yang diciptakan sendiri oleh siswa, dalam berbagai varian seperti berikut:

Hai yang selalu membuatku malu pada Rabb-ku, adalah amalku cacat, ibadahku berpenyakit, tapi karunia-Nya selalu sempurna

Petuah bijak ini merupakan ekpresi yang bersumber dari kreatifitas berpikir siswa yang dikombinasikan dengan nilai bijak. Dalam petuah ini, siswa direpresentesikan sebagai manusia yang memiliki amalan yang cacat, ibadah yang berpenyakit namun, tetap optimis dalam mengarungi kehidupan karena ampunan dari karunia Tuhan yang Maha Sempurna.

Ketika seseorang menghina kamu, itu adalah sebuah pujian bahwa selama ini mereka menghabiskan banyak waktu untuk memikirkan kamu, bahkan ketika kamu tidak memikirkan mereka (BJ. Habibie)

Bangsa yang besar adalah bangsa yang menghargai jasa pahlawannya (Sukarno) 
Kedua petuah bijak tersebut di atas merupakan representasi siswa dalam mengidolakan seorang tokoh beserta ungkapan-ungkapannya. Ungkapan pertama bernilai optimisme dan semangat bekerja di tengah berbagai macam kritikan. Sementara yang kedua anjuran menghargai jasa pahlawan Dari sini dilihat pandangan siswa tidak terfokus pada satu tema saja tetapi sangat variatif berdasarkan tuntutan pedoman hidup yang variatif pula. Ini bisa dilihat lebih jauh pada keragaman pesan bijak di dinding yang sama sebagai berikut:

Ada saatnya dalam hidupmu engkau ingin sendiri saja bersama angin menceritakan seluruh rahasia lalu meneteskan air mata

Cobalah belajar untuk menghargai sekecil apapun usaha seseorang karena berusaha itu tidak semudah berbicara

Untuk berbuat baik tidak perlu menunggu baik.

Mulailah melakukan kebaikan hingga kita menjadi lebih baik dan memberi kebaikan

Jangan hanya mencari kawan yang membuat kamu senang. Cari kawan yang dapat membuatmu berkembang

Mungkin kita dilahirkan untuk kalah tapi kita tidak dilahirkan untuk menyerah

Kita harus saling mengingat

Dosa jangan di (+),

Amal jangan di (-),

Cinta jangan di (:),

Hidup hanya se $(\mathrm{x})$

Menegur janngan sampai menghina

Mendidik jangan sampai memaki

Meminta jangan sampai memaksa

Memberi jangan sampai mengungkit

Nda Jaga Ibadah

Hari-hari Mabo

Pigi-pigi ba dugem

Kalakuang bisae kong

Cita-cita mo mao maso surga

Kypa nga ada orang dalam :p

Selalu ada waktu untuk tadarus

Hormat guru

No!!! bicara kotor

No!!! Buang sampah sembarangan
Kompak!!!

Harus saling memberi

Harus saling membantu

Tidak boleh saling menyakiti

Class should always be clean

Selalu bahagia

Tinggal 1 tahun

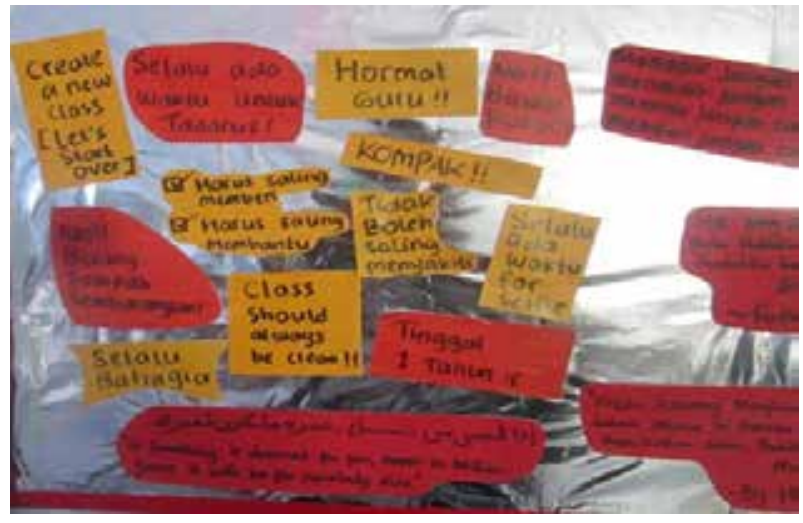

Gambar 1: Contoh Mading Siswa yang penuh dengan goresan petuah bijak. (Dokumen Syarifuddin)

Keberagaman petuah bijak tersebut di atas merupakan ekpsresi kreatifitas siswa dengan memanfaatkan daya kalbu dan pikiran siswa dalam bentuk petuah bijak. Ini kemudian diekspresikan lebihlanjutdengan menggunakan mediabahasayang dikuasai seperti bahasa Indonesia, Bahasa Melayu Manado serta bahasa asing. Tema yang diangkat pun cukup beragam yang pada intinya memotivasi dalam menjalani kehidupan sebagai siswa. Secara spesifik, pesan bijak yang terakhir diutarakan dalam berapa bait ungkapan yang menyebutkan aturan-aturan madrasah walaupun pada dasarnya mengingatkan dan memberatkan namun harus dijalani dengan baik demi kemaslahatan di masa depan. Karena duduk di bangku madrasah hanya sementara (tinggal 1 tahun) dan akan menyambut kehidupan yang lebih berat dan menantang.

Di samping ungkapan bijak dalam bentuk verbal yang cukup banyak di goresan dinding siswa, ekspresi bijak juga diungkapakan dalam bentuk visualisasi grafik namun makna yang dikandung cukup dalam dan inspiritif bagi siswa. Misalnya coretan siswa di kelas MIPA XII 6 dengan tema "Sosial Media" dengan Motto "Ekspresikan Semangat Juangmu" yang berwarna merah putih disamping gambar bendera merah putih yang mengindikasikan semangat HUT Proklamasi RI. Secara khusus, di dinding tidak didapatkan teks pesan bijak verbal kecuali kecuali motto yang 
disebutkan. Namun gambar visual berupa ikon sosial media seperti Facebook, Twitter, BBM, lampu, Google, dan lain sebagainya dengan cukup dominan. Dalam perspektif semiotika, gambar ini dimaknai sebagai ikon, symbol maupun indeks yang dikenal sebagai tanda (Pradopo, 2011: 120) yang merepresantasikan sebagai makna media sosial serta kebebasan dalam mengaksesnya (Rusmana, 2014: 110-111 ). Hanya saja kebebasan itu, dibatasi sebuah nilai yang moral yang sebagai pagar indeks pembatas yang dilambangkan dengan visualisasi "pagar" di bagian bawah dinding.

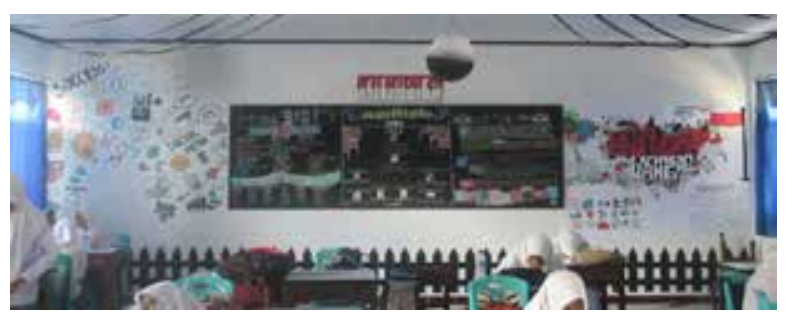

Gambar 2: Mading Siswa dengan icon sosial media. (Dokumen Syarifuddin)

\section{PENUTUP}

Kesimpulan dari penelitian ini yaitu variasi petuah bijak religi siswa yang siswa di MAN Model Manado cukup beragam yang sebigan besar bertipe aphoris, idiom, motto, dengan media bahasa yang bermacam-macam seperti bahasa daerah, bahasa Indonesia, bahasa Manado Melayu, Bahasa Asing (Arab dan Inggris). Secara khusus, petuah bijak lokal lebih banyak diungkapkan dalam Bahasa Melayu Manado. Hal ini terjadi karena penguasaan siswa terhadap bahasa daerah Minahasa maupun Bolango yang merupakan etnis besar di Sulawesi Utara sudah sangat minim.

Sumber literasi siswa terkait dengan ekspresi bijak awalnya diperoleh dari pesan-pesan orang tua (orang yang dituakan di lingkungan keluarga) serta ungkapan kearifan lokal sudah menjiwa pada diri siswa. Kearifan lokal ini mudah diperoleh oleh siswa salah satunya berkat sosialisasi massif pemerintah dalam bentuk anjuran secara lisan maupun dalam bentuk papan reklame di sudut kota maupun daerah. Khusus dalam lingkungan akademik madrasah, pesan bijak lebih banyak diperoleh dari pesan-pesan guru maupun papan reklame yang memuat nilai bijak. Selanjutnya, siswa mengespresikan nilai bijak tersebut dalam berbagai media seperti media sosial, latihan pidato maupun goresan di majalah dinding. Media terakhir inilah yang terlihat begitu dominan di tataran siswa MAN Model Manado.

\section{UCAPAN TERIMA KASIH}

Terima kasih kepada seluruh pihak yang turut membantu terlaksananya penelitian ini mulai dari awal sampai akhir. Terima kasih yang sedalamdalamnya kepada Dr. Hamzah, MA sebagai Kepala Balai Litbang Agama Makassar yang menugaskan peneliti sehingga penelitian bisa terlaksana. Terima Kasih juga kepada Bapak Dr. Idham, M.Pd di Bidang Lektur, Khazanah Keagamaan dan Manajemen Organisasi atas segala bimbingannya dalam pelaksanaan kegiatan penelitian. Demikian pula terima kasih kepada Ibu Sarpin Hamzah, Kepala MAN Model Manado, Ibu Irawati, Guru MAN Model Manado serta para siswa yang terlibat langsung dalam tahap pengumpulan data penelitian.

\section{DAFTAR PUSTAKA}

Adiputra, Wisnu Martha. Literasi Media dan Interpretasi atas Bencana. Jurnal JSP Volume 11 Nomor 3 Tahun 2008.

Arsyad, Azhar. 2005. Retorika Kaum Bijak: Media Pembangkit Motivasi dan Daya Hidup Serta Penanaman Nilai-nilai dan Budi Luhur. Makassar: Yayasan Fatiya.

Desmita. 2016. Psikologi Perkembangan Peserta Didik. Cet. VI; Bandung: Rosda Karya.

Djakaria, Salmin dan Hendri Gunawan. 2014. Ungkapan dan Tradisi Bercirikan Pembentukan Watak dan Karakter Bangsa: Suatu Kajian Nilai Budaya Minahasa. Yogyakarta: Kepel Press.

Eriyanto. 2001. Analisis Wacana: Pengantar Analisis Teks Media. Yogyakarta: LKIS.

Kusumo, Ganang Probo. 2013. Pengembangan Literasi Akademik Siswa di Sekolah. Skripsi, Bahasa, dan Sastra Indonesia. Universitas Negeri Malang.

Hidayat, Amir F dan Elis N. Rahmani AR. 2006. Ensiklopedi Bahasa-bahasa Dunia dan Peristilahan Dalam Bahasa. Jawa Barat: Pustaka Grafika.

Lilis, Dede. 2014. Media Anak Indonesia: Representasi Idola Anak dalam Majalah Anak-anak. Jakarta: Yayasan Pustaka Obor Indonesia.

Muslim, Abu. Kitorang Samua Basudara: Bijak Bestari di Bilik Harmoni. Jurnal Harmoni Volume 15 Nomor 2 Tahun 2016.

Pradopo, Rahmat Djoko. 2011. Beberapa Teori Sastra, Metode Kritik dan Penerapannya. Yogyakarta: Pustaka Pelajar.

Rattu, A.B.G. 1997. Bahasa Daerah di Minahasa 
dalam Profil Kebudayaan Minahasa. Tomohon: Majelis Kebudyaan Minahasa.

Rosdiana. Implementasi Pendidikan Karakter di MAN Model Manado. Jurnal Alqalam Volume 20 nomor 2 Tahun 2014.

Rusmana, Dadan. 2014. Filsafat Semiotika : Paradigma, Teori, dan Metode Interpretasi Tanda: dari Semiotika Struktural Hingga Dekonstriksi Praksis. Bandung: Pustaka Setia.

Sombowadile, Pitres. et. al. 2012. Kearifan Lokal Kaitannya dengan Pembentukan Watak dan Karakter Bangsa di Kabupaten Bolaang Mongondow Selatan. Yogyakarta: Kepel Press.

Sondakh, A.J. 2008. Arti, Nilai, Makna Filosofis: Tumou Tou, Menjadi Manusia Seutuhnya, Falsafah Hidup Orang (Tou) Minahasa. TT: Waya Media.

Sugiyono. 2010. Metode Penelitian Pendidikan (Pendekatan Kualitatif, Kuantitatif, dan
R\&D). Bandung: Alfabeta. Sugiyono. 2010. Metode Penelitian Pendidikan (Pendekatan Kualitatif, Kuantitatif, dan R\&D). Bandung: Alfabeta.

Sumampouw, Nono S. A. 2015. Menjadi Manado: Torang Samua Basudara, Sabla Aer, dan Pembentukan Identitas Sosial. Yogyakarta: Gadjah Mada University Press.

Tinggogoy, Jan. 2002. Arti, Nilai, Makna Filosofis: Si Tou Tumou Tou (Tou Minahasa): Refleksi Atas Nilai-nilai Manusia. Jakarta: Pustaka Sinar Harapan.

Zuleha. 2013. Pembelajaran Bahasa Indonesia: Apresiasi Sastra di Sekolah Dasar. Cet. II; Bandung: Rosda Karya.

Sumber Internet

https://en.wikipedia.org/wiki/Saying. diakses pada tanggal 7 Oktober 2016. 